\title{
Translating Idioms from Nepali into English
}

NABARAJ NEUPANE

\begin{abstract}
Idioms are precise prosaic expressions, which have unalterable forms, peculiar structures and figurative meanings. They are soluble into their culture and context. Therefore, they are one of the most difficult constituents of a language to recognize, interpret and translate. In such context, this study aimed to explore idiom translation strategies. In a corpus based research design, I selected forty-two idioms from six Nepali novels and their translations. By means of quantitative and qualitative analysis of the data, I found these strategies in use: idiom-to-idiom translation, literal translation, omission and paraphrase. This study implies that idiom-to-idiom translation is the best strategy.
\end{abstract}

Keywords: Idiom, Omission, Paraphrase, Strategy, Translation.

\section{Introduction}

Each language is unique because of its inalienable difficult and peculiar constituents like idioms, proverbs, fixed expressions, collocations and phrasal verbs, to mention a few. These are soluble parts which are difficult to identify for a non-native translator. Out of them, idioms are smaller bits of languages which are inextricably adhered to its culture and context. This is evidenced in Farahani and Ghasemi's (2012: 17) words, "Idioms $[\ldots]$ are embedded in the culture of language. Their roots are in culture, custom, history, religion, local condition, cultural background and even geography of a nation". Therefore, only acute observation enables one to recognize them in a discourse and to interpret their connotations. These 
are main hurdles for the translators of idioms. Despite their nuances of meanings, idioms require appropriate translation because otherwise the translators might slip off from conveying true meanings to the target text readers.

Translating idioms is one of the problem areas that translators are frequently grappled with. On the one hand, idioms may not be similar in two or more languages and on the other hand, their opaqueness makes them difficult for fluent translation. This happens because idioms are "extended metaphors" whose functions are referential (cognitive) and pragmatic (aesthetic) and are the bits of language used for "a kind of deception, often used to conceal an intention" (Newmark 1988: 104). However, Fernando (1996 as citied in Strakšiene 2009) has shown three functions of idioms, such as ideational (e.g. pull an invisible string, made a foot of myself), interpersonal (e.g. I beg your pardon, good morning) and relational (e.g. on the one hand...on the other hand, in addition). These functions confirm that idioms are figurative and idiosyncratic in nature. This is why; bilingual competency and cultural sensitivity are inevitable for idiom translation. Since there are difficulties for idiom translation across languages, one needs strategies and their applications for interlingual translation and for making sound judgment of the translated texts (especially, idioms).

Idioms are facilitative of maintaining fluency of expressions in translation. In this connection, Farahani (2005) has pointed out the translation of idiomatic expressions as an indicator of naturalness of the translated text (as cited in Farahani \& Ghasemi 2012). So, their translation is a test of a translator. Therefore, research into idiom translation strategies is required.

\section{Review of Related Literature}

Idioms are culture and context specific. Therefore, they have different conceptualisations, classifications and problems in 
different cultures and contexts. Accordingly, strategies vary for translating them. These are discussed in the succeeding subsections.

\section{Definitions}

Idioms, which are inextricable parts of a language, are found in most of the languages, although the terms vary, such as 'idiom' in English, tukkā or tukkā in Nepali, muhāvarā in Hindi and so on and so forth (Poudyāl 2003). They are defined in a number of ways by Nepali and foreign scholars, some of which are observed in the following paragraphs:

i An idiom is a number of words which, taken together, mean something different from the individual words of the idiom when they stand alone (McMordiew 1983 as cited in Strakšiene 2009: 13).

ii Idiom has two main meanings. First, idiom is a particular means of expressing something in a language, music, art and so on, which characterises a person or group. Secondly, an idiom is a particular lexical collocation or phrasal lexeme, peculiar to a language (Moon 1998, as cited in Strakšiene 2009: 13).

iii If any part of a sentence, a word or a term expresses a connotation or a figurative meaning, it is called an idiom (Pokhrel 1998: 122, My translation.).

iv Idioms are brief and incomplete expressions. They can be complete only if they are used in a sentence. They are in prosaic form (Poudyāl 2003: 31, My translation.).

$\mathrm{v}$ Idioms are frozen patterns of language which allow little or no variation in form [...] often carry meanings which cannot be deduced from their individual components. [...] a speaker or writer cannot normally do any of the following with an idiom: change the order of the words in it, delete a word from it, add a word to it, replace a word with another and change its grammatical structure (Baker 2011: 67). 
vi Idioms show figurative/connotative meaning (Parajulee 2012: 24, My translation.).

These definitions reveal some distinctive traits of idioms. The first definition shows their idiosyncratic nature that whole is not equal to the parts. It implies that the meanings and structures of idioms are not predictable and decipherable. The second definition shows that idioms have two meanings; the second one is similar to their nature as stated in the first definition. Unlike the first and the second ones, the third and the sixth definitions show that idioms have connotative / figurative meaning rather than conceptual/denotative one. The fourth definition adds that idioms are always prosaic. The fifth definition exhibits their rigidity. To sum up, Neupane (2017) has asserted, "Idioms are incomplete concise prosaic expressions, which have unalterable forms, peculiar structures and figurative meanings" (139). Therefore, idioms are epigrammatic, aphoristic and frozen in nature and form.

\section{Classifications}

Idioms are opaque expressions. However, Fernando (1996, as cited in Strakšiene 2009) classifies them into three types, out of which the third one is transparent. His first type is pure idiom, which is opaque and non-literal. For example: a dark horse, the salt of the earth, spill the beans, to mention a few. In these examples, 'horse', 'salt' and 'beans' have nothing to do with their idiomatic meanings. The second type is semi-idiom, which is semi-permeable. For example: to have an eye for, to hold her tongue, broke the news, give her a slip and so on. His third type is literal idiom, which is transparent. For example: of course, in any case, here you are, in the twinkle of an eye. Regarding the opaque/transparent dichotomy, Eftekhari (2008) adds that out of different types of idioms some are easily recognisable than others as they violate truth conditions and they do not follow the conventions of common language. 
Unlike this, Nepali scholars, like Pokhrel (1998) and Parajulee (2012) have classified idioms on the basis of their forms.

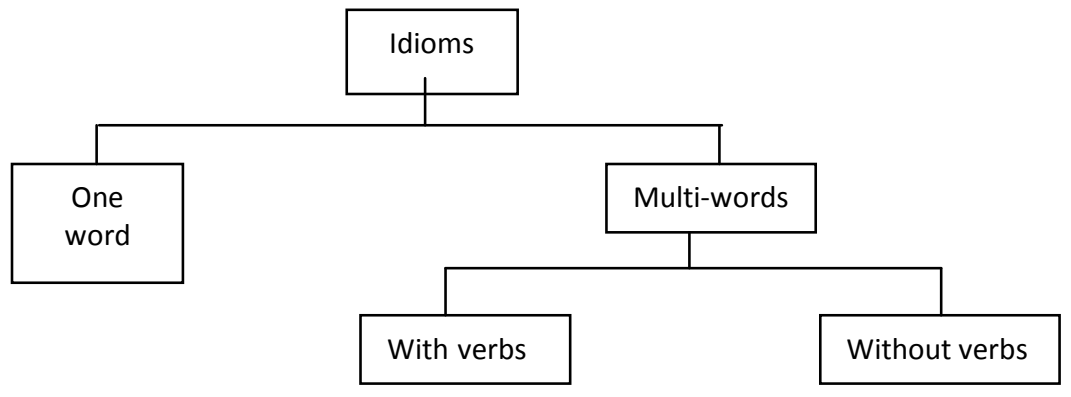

Figure1: Classifications of Idioms

Source: Adapted from Pokhrel 1998 \& Parajulee 2012

Figure 1 shows that $t u k k \bar{a}$ (idioms) in Nepali are of two types: one word and multi-word. One word idioms contain only one word, such as lakhane 'silly', bāiphāle 'shameless', pākhe 'uncivilised' and so on. Multi-word idioms contain two or more words. They can further be divided into two sub-types: with verbs and without verbs. The former type consists of a verb plus other word class members, for example: jibrotoknu 'to die', nākrākhnu 'to keep prestige', cilloghasnu 'to praise' and so on. The latter does not contain a verb, for example: māmākodhan 'property without labour', uniukophūl 'impossible thing', kāuchākomālā 'undesired thing' and so on.

\section{Distinction between Idioms and Proverbs}

Idioms and proverbs are frequently confused. Therefore, it is also appropriate to distinguish them before observing the translation of idioms. Although there are some similarities, the major differences are as follows:

i Idioms have primacy of lakșaṇa (secondary signification or implication) whereas proverbs have primacy of vyanjana (the last of the three powers of a word, suggested meaning). 


\section{Nabaraj Neupane}

ii Proverbs in sentence are forms whereas idioms are parts of the sentences.

iii Proverbs are both in verse and prose forms whereas idioms are always in prose.

iv Proverbs may tell a synopsis of a long story, event and context briefly. On the other hand, idioms express only a brief experience.

v Proverbs express a moral whereas idioms express social transactions.

vi Proverbs can be divided to make idioms but idioms cannot be extended to make proverbs (Poudyāl 2003 \& Parajulee 2012, as cited in Neupane 2017: 144).

These points show that both idioms and proverbs are components of culture specific concepts, yet they differ in terms of form, signification and functions.

\section{Difficulties}

Numerous translators and translation theorists have indicated different difficulties in translating idioms. Baker (2011) has attributed qualities of idioms in terms of "flexibility of patterning" and "transparency of meaning" (67). It means idioms have fixed and unalterable patterns and their meanings are opaque. Their unpredictable patterns incapacitate one to deduce meanings from the meanings of their constituents. That is why; the main difficulties in translating idioms are to recognize and interpret them and to render their playfulness. For example, go out with (take sexual or romantic relation with someone), take somebody for a ride (deceive or cheat someone in some way), drain the radiator (to urinate, or to use the toilet). She has presented examples which differ in culture specific contexts: to carry coals to Newcastle (English), to carry owls to Athens (German), to carry water to the river (French) and in Nepali it is suryakā agādi batti bālnu [to light a lamp in front of the sun]. Likewise, pigs might fly in English, 
cut off one's right arm in Arabic and kān kātera pātma rākhnu [cut of one's ear and put it on a leaf] have similar idiomatic senses. These idioms have both literal and idiomatic meanings. If a translator accepts their literal meanings, the text becomes misleading. Another difficulty, Baker (2011) notices, is to identify false friends across languages. For example, to pull one's leg in English means to make fun of somebody or to tease somebody. In Nepali khuttā tānnu [pull the legs] apparently mean similar but it is a false friend as it means "to stop others from doing progress" in Nepali. To sum up, Baker (2011) has enumerated and illustrated these difficulties involved in translating idioms:

i An idiom [...] may have no equivalent in the target language,

ii An idiom [...] may have a similar counterpart in the target language, but its context of use may be different.

iii An idiom may be used in the source text in both its literal and idiomatic senses at the same time.

iv The very convention of using idioms in which they can be used and their frequency of use may be different in the source and target languages (Baker 2011: 71-75).

These difficulties prove that a translator should highly be sensitive while translating across languages and cultures. Using idioms in English is a matter of style but in Nepali they are not normally used in written/formal discourse. Therefore, English - Nepali or Nepali - English translators should be aware of pitfalls and problems while translating culture specific concepts, especially idioms.

\section{Strategies}

Numerous difficulties (including the above mentioned ones) in translating idioms call for strategies to facilitate better translation. Different scholars have recommended different sets of strategies. Of them, Trosborg (1997, as cited in 
Strakšiene 2009) has recommended the use of two strategies, such as bringing the reader to the text and bringing the text to the reader. The former strategy refers to foreignization whereas the latter refers to domestication (Venuti 2008). The former preserves the originality of the source text whereas the latter maintains fluency and naturalness in the target text. Therefore, the former aims to produce SL-friendly whereas the latter TLfriendly version.

Out of many empirical studies, Strakšiene's (2009) study aimed to investigate the types of idioms and idiom translation strategies from English into Lithuanian. In a corpus-based approach, she selected 64 idioms from Agatha Christie's two novels Appointment with Death (2001) and Masterpieces of Murder: Death on the Nile (1977), which were translated from English into Lithuanian. She found three types of idioms like pure, semi-pure and literal. She also found that most frequently used strategy for translating idioms was by paraphrasing, followed by literal translation, idiom-to-idiom translation and omission, respectively. This shows that the translator tries to preserve source language properties in translation and tends to follow foreignization strategy (paraphrasing and literal translation) in translation. Further, the translator has used omission only as a last resort, which is justifiable.

Likewise, Dinçkan (2010) has studied translation of English culture-bound collocations into Turkish. By adopting survey research design, the researcher found five foreignizing strategies (translation using a loan collocation, literal translation, footnote, translation by paraphrase and translation by a collocation of similar meaning but dissimilar form); three domestication strategies i.e. neutralization, cultural substitution and omission; and a mixed strategy i.e. mistranslation. These strategies were originally discussed by Schleiermacher (1813, 
as cited in Venuti 2008). Of them, the researcher has claimed that domestication is easier and less time-consuming.

However, more reliable, valid and practicable set of strategies have been presented by Baker (2011) who has discussed these strategies for translating idioms: (a) using of an idiom of similar meaning and form; (b) using of an idiom of similar meaning but dissimilar form, (c) borrowing the source language idiom, (d) translation by paraphrase, (e) translation by omission of a play on idiom and (f) entire omission. These strategies have been implemented by different researchers home and abroad, including Neupane (2017), who has proved their effectiveness in translating texts. He has concluded so by testing these strategies in translating culture-specific concepts (including idioms) used in six novels which are translated from Nepali into English.

Further, Farahani and Ghasemi's (2012) study aimed to explore the strategies applied for translating idioms and proverbs in the Persian translation of an English version of The Adventures of Pinocchio, originally authored by an Italian novelist Colloid in Italian. This corpus-based research was based on product oriented descriptive translation studies. Based on the study of 200 idioms, the researchers found out that the best strategy was translation by paraphrasing. Other strategies they found in order of frequency were: using an idiom of similar meaning but dissimilar form, translation by omission and using an idiom of similar meaning and form. This study also found naturalness/idiomaticity of translation, in which translation reads not as translation but as original writing (Venuti 2008).

Based on these strategies, I have developed this set to explore the translation of idioms: (a) idiom-to-idiom translation, (b) paraphrasing, (c) literal translation and (d) omission. The first 
strategy subsumes translation of an idiom using similar meaning but similar/dissimilar form. This is supposed to be an ideal strategy and possible only in case of functional approximation across languages. The second one, i.e. paraphrasing includes rewording of SL idiom by using related/unrelated terms. The third one refers to the translation of an idiom by reducing it to an ordinary or literal sense and by deleting of word play on an idiom. Finally, the last resort theoretically, omission involves deletion of entire idiom.

\section{Methodology}

The main aim of this study was to explore the strategies used in translation of idioms from Nepali into English. To achieve this, I followed corpus-based study, which includes six novels as its universe. In this product-oriented descriptive translation study (Munday 2008), I collected forty-two idioms purposively from Nepali and English versions of the novels Phülko Atanka (Terror of Flower), Seto Bāgh (Wake of the White Tiger), Basāin (Mountains Painted with Turmeric), Dabali (Dabali), Muglān (Muglan) and Modiāin (Modiain- a Grocer's Wife). The technique for collecting data was the observation that was based on multi-word idioms (with/without verbs). These purposively selected forty-two idioms were transliterated using Turner and Turner's (2009) phonological symbols and were reexamined in light of the four strategies set in the literature review section of this study. The analysis followed descriptive and interpretive approach to draw inferences.

\section{Results and Discussion}

In the translation of selected idioms, I found the use of four strategies (Table 1). The most frequent strategy was idiom-to idiom translation $(57.14 \%)$. The other strategies in order of frequency were: literal translation (16.67\%), omission (14.29\%) and paraphrase (11.90\%), respectively. 
Translating Idioms from Nepali into English

\begin{tabular}{|l|l|l|l|}
\hline $\begin{array}{l}\text { S. } \\
\text { N. }\end{array}$ & Strategies Used & Frequency (N) & $\begin{array}{l}\text { Percentage } \\
(\%)\end{array}$ \\
\hline 1 & Idiom-to-idiom & 24 & 57.14 \\
\hline 2 & Literal translation & 7 & 16.67 \\
\hline 3 & Omission & 6 & 14.29 \\
\hline 4 & Paraphrase & 5 & 11.90 \\
\hline 5 & Total & 42 & 100.00 \\
\hline
\end{tabular}

Table 1: Strategies Used for Translating Idioms

These data reveal that idiom-to-idiom translation is the best strategy for translating idioms, which are soluble constituents of a language. Despite this, other strategies like literal translation, omission and paraphrase can also be used as legitimate ones.

\section{Idiom-to-Idiom Translation}

Out of the four strategies, idiom-to-idiom translation is considered to be the best alternative. In this, idiom match between the donor and the receiver languages are investigated. In this sense, this strategy is like Venuti's (2008) domestication, in which translation reads not like translation but like the original one. This strategy, in this research, subsumes Baker's (2011) use of an idiom of similar meaning and form and use of an idiom of similar meaning but dissimilar form.

Use of an idiom of similar form and meaning, in table 2, demonstrates two types of idioms like without verbs (e.g. 1, 2, $13,15)$ and with verbs (e.g. 3, 4, 5, 6, 7, 8, 9, 10, 11, 12, 14). In both the instances, SL idioms have TL matches in the form of idioms themselves. For example, mānisharuko bā [humankind's over flooding] is similar to its English translation 'the ocean of humanity'; and hāta pārnu [to own something] is similar to its English counterpart 'to rip off'. In these examples, both SL and TL idioms have same form and meaning. 
Nabaraj Neupane

Table 3 also exhibits the two types of idioms, like one verbless (e.g. 18) and other with verbs. Unlike in the instances of table 2, the meanings in SL and TL are similar but forms are different. For example, ghaĩtomā ghām lāgnu [to become something clear] is similar in meaning but dissimilar in lexemes of its English counterpart 'something flashes in his mind'. In this example, SL idiom is a part of a sentence but TL one is a simple complete sentence. Yet, both SL and TL versions are idiomatic.

Tables 2 and 3 verify Baker's (2011) assertion that the translators should seek TL matches for SL idioms at their first attempt, albeit they may be of similar or dissimilar forms. To be specific, use of similar meaning and form, which has been justified from these data, should be the first priority of the translators.

\begin{tabular}{|c|c|c|}
\hline S.N. & Nepali Idioms & Translated Forms \\
\hline 1 & $\begin{array}{l}\text { *Ek myānmā duī tarbār. (p. } \\
205)\end{array}$ & $\begin{array}{l}\text { Two swords in one sheathe. } \\
\text { (p. 193) }\end{array}$ \\
\hline 2 & $\begin{array}{l}\text { *āphnai duno sojhyāunu. } \\
\text { (p. 249) }\end{array}$ & $\begin{array}{l}\text { To take stock of new-found } \\
\text { affluence (p. 237) }\end{array}$ \\
\hline 3 & •Risl edāhrā kiṭnu. (p. 34) & $\begin{array}{l}\text { To grind his teeth angrily. (p. } \\
59 \text { ) }\end{array}$ \\
\hline 4 & •Hātm & $\begin{array}{l}\text { To put hands into their } \\
\text { mouths. (p. } 65 \text { ) }\end{array}$ \\
\hline 5 & •Suĩkuccā thoknu. (p. 51) & To take to her heels. (p. 87) \\
\hline 6 & •Nīc mārnu. (p. 38) & To give up. (p. 65) \\
\hline 7 & $\begin{array}{l}{ }^{a} \text { Sabai mūlā eutai dyāno } \bar{a} \text {. } \\
(p .10)\end{array}$ & $\begin{array}{l}\text { All peas of the same pod. (p. } \\
20 \text { ) }\end{array}$ \\
\hline 8 & $\begin{array}{l}{ }^{a} \text { Akka na bakka hunu. (p. } \\
\text { 24) }\end{array}$ & $\begin{array}{l}\text { Not to know what to do. (p. } \\
48 \text { ) }\end{array}$ \\
\hline 9 & $\begin{array}{l}{ }^{a} \text { Ghyāmpā bhitra luknu. (p. } \\
\text { 109) }\end{array}$ & $\begin{array}{l}\text { Take ostrich-like positions. } \\
\text { (p. 238) }\end{array}$ \\
\hline 10 & $\begin{array}{l}\text { ^ Tikhā ã } k^{2} \bar{a} \text { pharkāunu. (p. } \\
\text { 2) }\end{array}$ & $\begin{array}{l}\text { To pop the shrewd eyes. (p. } \\
\text { 3) }\end{array}$ \\
\hline 11 & ${ }^{\wedge} \bar{A} k h a \bar{k} o$ viṣ mārnu. (p. 7) & $\begin{array}{l}\text { To kill the sting of the eyes. } \\
\text { (p. 12) }\end{array}$ \\
\hline 12 & ^ Hāta pārnu. (p. 13) & To rip off. (p. 22) \\
\hline
\end{tabular}


Translating Idioms from Nepali into English

\begin{tabular}{|l|l|l|}
\hline 13 & ^Seto hiũko kātro. (p. 47) & $\begin{array}{l}\text { The white coffin of snow. (p. } \\
77)\end{array}$ \\
\hline 14 & $\begin{array}{l}\text { 'Siyoko țuppojati pani māto } \\
\text { nadinu. }(p .36)\end{array}$ & $\begin{array}{l}\text { Not giving up any land. (p. } \\
42)\end{array}$ \\
\hline 15 & $\begin{array}{l}\text { 'Mānisharuko bādhi. (p. } \\
\text { 33) }\end{array}$ & $\begin{array}{l}\text { The ocean of humanity. (p. } \\
45)\end{array}$ \\
\hline
\end{tabular}

Table 2: Use of Similar Meaning and Form

Note: The page numbers against Nepali idioms refer to the pages of Nepali version of the selected novels and the ones in English translations refer to the pages in English versions.v

Examples from*Seto Bāgh, aPhulko Atanka, •Basain, ${ }^{a}$ Dabāli, ^ Muglān and ${ }^{~}$ Modiāin.

\begin{tabular}{|c|c|c|}
\hline S.N. & Nepali Idioms & Translated Forms \\
\hline 16 & $\begin{array}{l}\text { aGhã ți herī häd nilnu. } \\
\text { (p. 64) }\end{array}$ & $\begin{array}{l}\text { Cut your coat according to your } \\
\text { cloth. (p. } 48 \text { ) }\end{array}$ \\
\hline 17 & ๙Kān kāṭu. (p. 68) & To cut down to size. (p. 53) \\
\hline 18 & $\begin{array}{l}\text {-Strisulav lājkā rekhā. } \\
\text { (p. 7) }\end{array}$ & $\begin{array}{l}\text { An expression of natural } \\
\text { womanly modesty. (p. 12) }\end{array}$ \\
\hline 19 & •Kurā țālnu. (p. 10) & To disobey. (p. 18) \\
\hline 20 & •Kān khānu. (p. 19) & To d \\
\hline 21 & -Mekh mārnu. (p. 30) & To strike a bl \\
\hline 22 & -Kansirì tātnu. (p. 34) & Ears burn. (p. 58) \\
\hline 23 & ${ }^{a}$ Hairān hunu. (p. 12) & At their wit's end. (p. 23) \\
\hline 24 & $\begin{array}{l}{ }^{a} \text { Ghaĩtomā ghàm lāgnu. } \\
\text { (p. 42) }\end{array}$ & $\begin{array}{l}\text { Something flashes in his mind. } \\
\text { (p. 90) }\end{array}$ \\
\hline
\end{tabular}

Table 3: Use of Similar Meaning but Dissimilar Form

\section{Literal Translation}

When the translator fails to find the match between the SL and the TL, literal translation is the way out. Literal translation is a good strategy when, "the SL grammatical constructions are converted to their nearest TL equivalents but the lexical words are again translated singly, out of context" (Newmark 1988: 46). It entails that, in this strategy, SL idiomatic expressions are reduced to literal senses. That is why; literal translation strategy is SL-friendly unlike idiom-to-idiom translation. 
Nabaraj Neupane

Table 4 exemplifies some instances of literal translation. For example, kurā capāunu [to talk by concealing the main thing] is a Nepali idiom but it has been translated as a sense into English. Likewise, mukhmā moso dalnu [to deface someone] is an idiom in SL but its counterpart in English is not. In these examples (from 25-30), wordplay in SL has also been omitted in TL in the name of preserving SL grammaticality. This demonstrates that literal translation is like Venuti's (2008) foreignisation, in which the translation reads not as an original text but as a translation.

\begin{tabular}{|c|c|c|}
\hline S.N. & Nepali Idioms & Translated Forms \\
\hline 25 & •Kurā capāunu. (p. 24) & To chew over. (p. 40) \\
\hline 26 & $\begin{array}{l}\text { •Mukhko lālì harāunu. (p. } \\
\text { 39) }\end{array}$ & $\begin{array}{l}\text { To drain one's face colour. } \\
\text { (p.39) }\end{array}$ \\
\hline 27 & •Mukh lukāunu. (p. 46) & To hide. (p. 79) \\
\hline 28 & $\begin{array}{l}\text { - Ākhābāța } \tilde{\bar{a}} \text { suko jharī } \\
\text { lāgirahanu. (p. 61) }\end{array}$ & $\begin{array}{l}\text { To pour tears from one's } \\
\text { eyes. (p.102) }\end{array}$ \\
\hline 29 & •Kurāko phūl joḍnu. (p. 38) & $\begin{array}{l}\text { To embroider it with flowers. } \\
\text { (p. 66) }\end{array}$ \\
\hline 30 & $\begin{array}{l}\cdot \text { Mukhmā moso dalnu. (p. } \\
\text { 79) }\end{array}$ & $\begin{array}{l}\text { To rub soot in the faces. (p. } \\
\text { 79) }\end{array}$ \\
\hline 31 & $\wedge$ Man amilinu. (p. 42) & Feel deeply maimed. (p. 48) \\
\hline
\end{tabular}

Table 4: Literal Translation in Translating Idioms

\section{Omission}

Omission is used as a legitimate strategy to maintain fluency of the translated text. This strategy, therefore, is TL-friendly. Though it is not justifiable, the SL idioms like corko dāhrimma ruwā (cotton on the thief's beard), man marnu (to die one's heart), man cornu (to test), kiriyā khānu (to swear), bhã pot) and gāḍ̄ samātnu (to catch a vehicle) are omitted in translation (Table 5).

\begin{tabular}{|l|l|l|}
\hline S.N. & Nepali Idioms & Translated Forms \\
\hline 32 & *Corko dāhrimmā ruwā (p. 43) & $\ldots$ \\
\hline 33 & $*$ Man marnu. $($ p. 85$)$ & $\ldots$ \\
\hline
\end{tabular}


Translating Idioms from Nepali into English

\begin{tabular}{|c|c|c|}
\hline 34 & *Man cornu. $(p .105)$ & $\ldots$ \\
\hline 35 & *Kiriyāk hānu (p. 148) & $\ldots$ \\
\hline 36 & $\begin{array}{l}\text { *Bhã } \bar{a} \bar{a} m \bar{a} \text { na bhuĩmā huпи. } \\
\text { (p. 222) }\end{array}$ & $\cdots$ \\
\hline 37 & ${ }^{1}$ Găḍ̂̀ samātnu. (p. 41) & $\ldots$ \\
\hline
\end{tabular}

Table 5: Omission in Translating Idioms

This verifies that omission can be used as a possible strategy in case the idioms in question are untranslatable and are not significant in the transference of the meaning. Nevertheless, the translators should be aware of their roles in the texts both the source and the target.

\section{Paraphrase}

Translation by paraphrase is a strategy in which a translator uses less expressive or more neutral terms in place of idiomatic expressions. It is also an explication of a condensed SL idiom to TL one. This claim is evidenced in these examples (Table 6): dāhine hātko khel [easy performance] and tolāyera hernu [to gaze] are paraphrased unidiomatically as 'an easy trick that the hand performs' and 'to look around in awe'. Similar instances are obvious in other translations as well in table 6.

\begin{tabular}{|c|c|c|}
\hline S.N. & Nepali Idioms & Translated Forms \\
\hline 38 & $\begin{array}{lcc}\text { *Din } & \text { dugunā } & \text { rāt } \\
\text { caugunā. }(p .190) & \end{array}$ & $\begin{array}{l}\text { Lavish donations endeared Jagat } \\
\text { even more to the rank and file. } \\
\text { (p. 179) }\end{array}$ \\
\hline 39 & ${ }^{a}$ Rị tirnu. $(p .12)$ & $\begin{array}{l}\text { To convey his gratefulness. (p. } \\
\text { 13) }\end{array}$ \\
\hline 40 & $\begin{array}{l}\text { ^ Dāhine hätko khel. (p. } \\
\text { 13) }\end{array}$ & $\begin{array}{l}\text { An easy trick that the hand } \\
\text { performs. (p. 22) }\end{array}$ \\
\hline 41 & ${ }^{1}$ Tolāyera hernu (p. 6) & to look around in awe (p. 8) \\
\hline 42 & ${ }^{1}$ Bhubhär hārn & $\begin{array}{l}\text { to be a catharsis of all evil (p. } \\
42 \text { ) }\end{array}$ \\
\hline
\end{tabular}

Table 6: Paraphrasing in Translation

Table 6 confirms that paraphrasing idioms across languages is a better strategy than omitting them. Yet, explication of idioms 
to the ordinary wordings can be a cause of the loss of cultural load, naturalness and fluency of the SL into TL. Further, if paraphrased wrongly, the text can be misleading.

\section{Conclusion and Implication}

Idioms, which are typical cultural expressions, are one of the main hurdles to cross in the translation field. The translators have to face the nuances of meaning in translating them. The problems are to recognize, to interpret and to render them across cultures. Despite these, translation of idioms is important as they are integral part of a language.

This study reveals that these four strategies are useful for translating idioms: (a) idiom-to-idiom translation, (b) literal translation, (c) omission and (d) paraphrase. Out of them, the first one, which subsumes the use of similar meaning and similar/dissimilar form, is an ideal strategy, albeit other three are also plausible. Further, use of paraphrase is a last resort for translating idioms because it creates many gaps in SL and TL versions.

This implies that the idiom translators should explore TL idioms to replace SL ones as far as possible because otherwise the translated text might lose readability and intelligibility. However, when the matches are not found, the idioms could be translated literally by reducing idiomatic expressions into literal senses. Further, omission is permitted if the SL idioms in question do not contribute to the understanding of the text. Finally, the translators should paraphrase SL idioms into TL only if other strategies fail. Yet, they should be aware of the sensitivity and style of the SL idioms while translating across languages and cultures.

\section{References}

BAKER, MonA. 2011. In Other Words: A Course Book on Translation ( $2^{\text {nd }}$ ed.). London \& New York: Routledge. 
Bhattarai, Govinda R. 2011. Muglān (5 ${ }^{\text {th }}$ ed.). Kathmandu: Oriental Publication. First published 1975.

Bhattarai, Govinda R. 2012. Muglan. (Tr.) L. S. Pathak. Kathmandu: Oriental Publication.

ChetTri, LiL B. 2008. Mountains Painted with Turmeric. (Tr.) M. J. Hutt. New York: Columbia University Press.

CHETTRI, LIL B. 2009. Basāin (Migration) $\left(34^{\text {th }}\right.$ ed.). Lalitpur: Sajha Prakashan. First published 1957.

DeVkota, Rajeshwor. 2002. Dabali (The Square). Lalitpur: Sajha Prakashan.

Devkota, Rajeshwor. 2011. Journey's End. (Tr.) H. Upadhyay. New Delhi: Adarsh Books.

DINÇKAN, YESIM. 2010. Culture-bound Collocations in Bestsellers: A Study of Their Translations from English into Turkish. Meta: Translators' Journal 55(3). 456-473. doi: 10.7202/045065ar.

EftekHArI, Negar. 2008. A Brief Overview on Idiomatic Translation. Retrieved from www.translationdirectly.com. FARAHANI, Aliakabar K.; and GHASEMI, MaSOUMEH. 2012. The Naturalness in Translation of Idioms and Proverbs: The Case of a Persian Translation of Pinocchio. Journal of Language and Translation 3(1). 17-22. Online: https://pdfs.semanticscholar.org/0015/1f98aa46a6b27b8d91 63609412b04145c60e.pdf

Gautam, Dhruba C. 2005. Terror of flower. (Tr.) P. H. Pierce. Kathmandu: Ratna Pustak Bhandar.

Gautam, Dhruba C. 2010. Phülko ātañka (Terror of Flower). Lalitpur: Sajha Prakashan. First published 1998.

KoIRALA, BishweshoR P. 2009. Modiāin ( $8^{\text {th }}$ ed.). Lalitpur: Sajha Prakashan. First Published 1979.

KoIRALA, BishweShOR P. 2012. Modiain. (Tr.) J. R. Acharya. Kathmandu: Centre for Democracy and Development. 
Nabaraj Neupane

MundAY, JEREMY. 2008. Introducing Translation Studies: Theories and Applications ( $2^{\text {nd }}$ ed.). London and New York: Routledge.

Neupane, NabARAJ. 2017. Strategies Used in Translation of Culture Specific Concepts: Exploration into Nepali Novels (Unpublished doctoral dissertation). Tribhuvan University, Kathmandu, Nepal.

NeWMARK, PeTER. 1988. A Textbook of Translation. London: Prentice Hall.

PARAJUlEE, KRISHNA P. 2012. Nepali ukhān ra gaũkhāne kathā (Nepali Proverbs and Riddles) ( $8^{\text {th }}$ ed.). Kathmandu: Ratna Pustak Bhandar.

POKHREL, BAL K. 1998. Raștrabhāṣā (National Language) (10 ${ }^{\text {th }}$ ed.). Lalitpur: Sajha Prakashan.

Poudyal, ShIVA P. 2003. Nepali ukhān ko viṣayātmak adhyayan (Nepali Novels: A Subjective Study). Kathmandu: Royal Nepal Academy.

Rana, Diamond S. 2010. Seto Bāgh (White Tiger). Lalitpur: Sajha Prakashan. First published 1973.

Rana, Diamond S. 1984. Wake of the White Tiger. (Tr.) G. Rana. Kathmandu, Nepal: Balika Rana.

STRAKŠIENE̊, MARGARITA. 2009. Analysis of Idiom Translation Strategies from English into Lituanian. Studies about Languages 14. 13-19. Online: www.kalbos.it/zurnalai/14_numeris/03.pdf.

Turner, RAlPh L.; and TURner, Dorothy R. 2009. A Comparative and Etymological Dictionary of the Nepali Language. New Delhi: Adarsh Books.

VENUTI, LAWRENCE. 2008. The Translator's Invisibility: A History of Translation ( $2^{\text {nd }}$ ed.). London \& New York: Routledge. 